\title{
Rapid diagnosis of bacterial infections using technologies based on nucleic acid detection
}

\author{
François J Picard PhD, Michel G Bergeron MD FRCP
}

\begin{abstract}
FJ Picard, MG Bergeron. Rapid diagnosis of bacterial infections using technologies based on nucleic acid detection. Can J Infect Dis 1999;10(Suppl C):16C-24C.

Bacterial identification and antibiotic susceptibility testing methods used in clinical microbiology laboratories generally require at least two days. This long delay often forces physicians to treat patients presumptively with broad-spectrum antibiotics. Novel diagnostic tests based on the detection of nucleic acids (DNA or RNA) offer a great potential for the rapid (approximately $1 \mathrm{~h}$ ) diagnosis of bacterial infections. The present article reviews various aspects of the development and validation of nucleic acid-based assays suitable for the detection and identification of bacteria as well as for the detection of associated antibiotic resistance genes. The potential of these assays for routine use in clinical microbiology laboratories is also discussed.
\end{abstract}

Key Words: Bacterial infections; DNA; Genetic methods; Nucleic acids; Rapid diagnosis; RNA

\section{Diagnostic rapide des infections bactériennes au moyen de techniques basées sur la détection des acides nucléiques}

RÉSUMÉ : Les méthodes couramment utilisées dans les laboratoires de microbiologie clinique pour l'identification bactérienne et pour la détermination de la sensibilité aux antibiotiques requièrent en général au moins deux jours. Ce long délai force fréquemment les médecins à traiter les patients de façon présomptive avec des antibiotiques à large spectre. De nouveaux tests diagnostiques basés sur la détection des acides nucléiques (ADN ou ARN) pourraient s'avérer une excellente alternative pour le diagnostic rapide (environ une heure) des infections bactériennes. Cet article présente une revue des différentes étapes du développement et de la validation d'essais reconnaissant spécifiquement ces acides nucléiques pour la détection et l'identification de bactéries ainsi que pour la détection de gènes de résistance associés. L'application clinique de ces essais pour usage dans les laboratoires de microbiologie clinique est également discutée.

I nfectious diseases are responsible for more than 17 million deaths worldwide per year, and bacterial infections are the cause of a high percentage of these infections $(1,2)$. The emergence of antibiotic resistance in bacteria is an increasingly serious problem that complicates treatment. The inappropriate use of antibiotics and the use of broad spectrum antibiotics are associated with this increasing rate of resistance (3).
Clearly, the health care costs associated with bacterial infections are enormous and growing.

The usefulness of clinical microbiology laboratory results provided to practicing physicians is highly dependent on timely identification and susceptibility testing of microbial pathogens. While other laboratories, such as biochemistry and hematology laboratories, provide clinically relevant re- 
TABLE 1

Clinically important bacteria for which the whole genome has been sequenced

\begin{tabular}{|c|c|c|c|}
\hline Bacteria & $\begin{array}{l}\text { Genome } \\
\text { size }(\mathrm{Mb})\end{array}$ & Sequencing status & Institution \\
\hline Bacillus subtilis & 4.20 & Complete & International consortium led by Institut Pasteur (France) and Nara (Japan) \\
\hline Borrelia burgdorferi & 1.44 & Complete & The Institute for Genomic Research (Maryland) \\
\hline Chlamydia trachomatis & 1.05 & Complete & $\begin{array}{l}\text { Berkeley University and the Stanford DNA Sequence and Technology Center } \\
\text { (California) }\end{array}$ \\
\hline Escherichia coli & 4.60 & Complete & University of Wisconsin (Wisconsin) \\
\hline Haemophilus influenzae & 1.83 & Complete & The Institute for Genomic Research (Maryland) \\
\hline Helicobacter pylori & 1.66 & Complete & The Institute for Genomic Research (Maryland) \\
\hline Mycobacterium tuberculosis & 4.40 & Complete & The Sanger Centre (United Kingdom) \\
\hline Mycoplasma genitalium & 0.58 & Complete & The Institute for Genomic Research (Maryland) \\
\hline Mycoplasma pneumoniae & 0.81 & Complete & University of Heidelberg (Germany) \\
\hline Neisseria gonorrhoeae & 2.20 & Almost complete & University of Oklahoma (Oklahoma) \\
\hline Neisseria meningiditis & 2.30 & Almost complete & The Sanger Centre (United Kingdom) \\
\hline Pseudomonas aeruginosa & 5.90 & Complete & $\begin{array}{c}\text { University of Washington Genome Center (Washington)/PathoGenesis } \\
\text { Corporation (Washington) }\end{array}$ \\
\hline Rickettsia prowazekii & 1.10 & Complete & University of Uppsala (Sweden) \\
\hline Staphylococcus aureus & 2.80 & Complete & Genome Therapeutics Corporation (Maryland) \\
\hline Streptococcus pyogenes & 1.98 & Almost complete & University of Oklahoma (Oklahoma) \\
\hline Treponema pallidum & 1.14 & Complete & The Institute for Genomic Research (Maryland)/University of Texas (Texas) \\
\hline Ureaplasma urealyticum & 0.75 & Complete & University of Alabama (Alabama)/Perkin-Elmer (Conneticut) \\
\hline
\end{tabular}

Mb Mega base. One $\mathrm{Mb}$ is equivalent to $1 \times 10^{6}$ nucleotides

sults within $1 \mathrm{~h}$ of sampling, even the most sophisticated systems of bacterial identification and susceptibility testing require several days because they rely on the growth and isolation of micro-organisms. In fact, clinical microbiology procedures are still based on the use of the same growth-dependent biochemical tests developed by Pasteur and others during the past century as well as on the culture-based disk-diffusion method for antimicrobial susceptibility testing developed in 1966 by Bauer et al (4). Consequently, the actual state-of-theart technology still requires a culture of 18 to $24 \mathrm{~h}$ to determine whether a clinical specimen contains bacteria. This is of importance because more than $80 \%$ of normally sterile specimens are negative for bacterial culture (5). Furthermore, current bacterial identification systems require an additional day for species identification by culture-based biochemical tests. The lack of a timely response by the clinical microbiology laboratory has important consequences on antibiotic use and prescribing (6). Patients must be treated empirically. When severe or nosocomial infections are suspected, they have been treated with broad-spectrum antibiotics. The increased use of toxic and expensive broad-spectrum antibiotics is not restricted to patients hospitalized in intensive care units or seen in emergency rooms; it is also observed in the treatment of common infections by office-based physicians (7). Clearly, a number of patients receive antibiotics even if they do not have a bacterial infection because of the delays of at least 18 to $24 \mathrm{~h}$ associated with microbial culture. The latter argument is supported by a recent study from Spain showing that on any given day the number of antibiotic prescriptions exceeded the number of diagnosed bacterial infections by three times (8). In fact, physicians rarely consult the microbiology results (gener- ally available in two to three days) unless the patient is not responding to the antibiotic prescribed.

To be useful to the clinician, microbiology results should be available within $1 \mathrm{~h}$ after specimen sampling, together with other clinically relevant results from radiology, and hematology and biochemistry laboratories. This is very important because the initial management and treatment of the patient are decided soon after these results are available. The concomitant availability of microbiology results provides physicians with important information, allowing optimal clinical management and treatment of patients. Furthermore, this approach may revolutionize the practice of medicine and provide an essential tool for the development and proper use of antibiotics, anti-endotoxins and biological response modifiers (5).

The advent of recombinant DNA technologies in the 1970s and their full development in the 1980s revolutionized many aspects of biological sciences, including the diagnosis of infectious diseases. After the first description of the use of DNA probes to detect enterotoxigenic Escherichia coli cultivated from stool specimens (9), hopes were high that DNA probe technologies would eventually replace standard culturebased methods. However, DNA probes showed a lack of sensitivity for direct detection from clinical specimens, and initial protocols for nucleic acid isolation were complex and required at least several hours. More recent technological advances related to sample preparation, nucleic acid amplification methods, such as the well known polymerase chain reaction (PCR), and rapid detection of amplification products should accelerate the implementation of diagnostic tests for bacteria based on nucleic acid detection in routine microbiology laboratories. 
Furthermore, the rapidly accumulating nucleotide sequence data for a variety of bacterial species offer great potential for the development of effective nucleic acid-based assays for the diagnosis of bacterial infections. The purpose of this article is to provide a critical review of the important steps involved in the development and validation of assays based on the detection of nucleic acids (DNA or RNA) that are suitable for the accurate and rapid diagnosis of bacterial infections. Various aspects of nucleic acid target selection, sample preparation, amplification technologies and detection methods are discussed.

\section{DEVELOPMENT OF OPTIMAL NUCLEIC ACID-BASED ASSAYS}

Genetic target selection - Database sequences: The rapidly growing database of nucleotide sequences from a wide variety of bacteria provides an essential tool for the selection of genetic targets suitable for diagnostic purposes. This tremendous sequence information is available in the public databases GenBank (Los Alamos, New Mexico) and European Molecular Biology Laboratories (EMBL, Heidelberg, Germany). In the past five years, microbial genomic analysis has been enjoying exponential growth, and microbial genomes are now sequenced at a very rapid pace $(10,11)$. Today, there are more than 14 genomes of clinically important bacterial species entirely sequenced and many others for which large portions of the chromosome have been sequenced (Table 1). This wave of genetic information, which also includes sequences from a variety of antibiotic resistance genes (Table 2), is directly associated with the improving efficacy and accuracy of automated DNA sequencers during the past decade. This abundance of genetic information provides a good choice of targets suitable for a variety of diagnostic purposes including bacterial identification and detection of antibiotic resistance. However, there are still many bacterial genes to be sequenced, and strong sequencing efforts are still required for many years to generate the genetic information required to develop effective assays for the detection and identification of all clinically important bacteria and associated resistance genotypes.

Target for bacterial detection and identification: The choice of a genetic target suitable for the specific detection of a bacteria is critical. The target nucleotide sequence (DNA or RNA) to be detected should be stable and specific for the target organism. For example, an assay for the specific detection and identification of Staphylococcus epidermidis must be based on a genetic target (DNA or RNA) that is well conserved in $S$ epidermidis but distinct from the corresponding nucleotide sequence in other bacterial species, including closely related species such as other coagulase-negative staphylococci. Similarly, an assay for the specific detection and identification of bacteria of the genus Staphylococcus must rely on a genetic target that is highly conserved in all Staphylococcal species, but that is distinct in closely related genera such as Streptococcus, Enterococcus, Listeria and Lactobacillus. Nucleic acid-based assays may also target a wider range of bacteria by using more conserved nucleotide sequences. For example, these assays may allow the universal detection of bacteria in normally sterile clinical specimens. Such an assay must target sequences very highly conserved in all bacteria in order to allow the efficient detection of any clinically relevant bacterial species. Another possibility is the development of assays specific for bacterial groups such as families (eg, Enterobacteriaceae and Pseudomonadaceae). In that case, the genetic target would have a level of conservation that is lower than that of sequences suitable for the universal detection of bacteria but higher than that of sequences appropriate for genusspecific detection. Therefore, the level of conservation of the targeted nucleotide sequences through bacterial evolution is the key factor to attain the desired specificity (ie, detection at the species, genus or family levels or, alternatively, for the universal detection of bacteria).

Carl Woese, the father of bacterial phylogenetics, used the term 'signature sequence' to refer to unique sequences of ribosomal DNA or RNA (rRNA) that allowed one species or a group of species to be distinguished from another $(12,13)$. These signature sequences are very useful for diagnostic purposes because their specific detection permits microbial identification at the species or higher taxonomic levels (12-17). Conserved genes other than those coding for rRNA (eg, tuf coding for a translation elongation factor and the gene encoding the HSP60 heat shock protein) also have signature sequences suitable for diagnostic purposes (18-20). Bacterial genes have different levels of conservation depending on their function in the cell. Genes highly conserved through bacterial evolution are always involved in essential functions of the cell and are constantly challenged by a strong selective pressure. These highly conserved genes offer great potential for the universal detection of bacteria or for detection at the genus or family levels (14-19). Furthermore, highly conserved nucleotide sequences suitable for universal detection of bacteria or for bacterial detection at the genus or family levels may be interspersed by more variable sequences that may be exploited for species-specific detection of bacteria (15-17). On the other hand, less conserved genes associated with species-specific functions or coding for protein having less selective pressure may be suitable for the development of species-specific nucleic acid-based assays (21-26).

of all genetic targets, the bacterial $16 S$ rRNA genes offer the greatest potential for the development of nucleic acidbased assays because they contain highly conserved nucleotide sequences suitable for the universal detection of bacteria, have variable regions suitable for bacterial detection and identification at the genus or species levels, and often occur in multiple copies per genome, thereby providing extra sensitivity $(16,17)$. Another important advantage of this target is that the phylogenetic analysis of bacteria now primarily using $16 \mathrm{~S}$ rRNA genes have provided sequences from a wide variety of bacterial species (12). Consequently, there are now more than six thousand bacterial 165 rRNA sequences available in public databases. This invaluable sequence information greatly facilitates the development of optimal assays for the rapid diagnosis of bacterial infections. On the other hand, there are other conserved genetic targets that may also be suitable for a variety of diagnostic purposes. The authors have been generating sequence data from a wide variety of clinically relevant 
TABLE 2

Clinically important antibiotic resistance genes

\begin{tabular}{|c|c|c|}
\hline Resistance genes & Antibiotics & Bacteria* \\
\hline $\operatorname{aac}(3)$ & Aminoglycosides & Enterobacteriaceae, Pseudomonadaceae \\
\hline $\operatorname{aac}\left(6^{\prime}\right)-\operatorname{aph}\left(2^{\prime \prime}\right)$ & Aminoglycosides & Enterococcus species, \\
\hline $\operatorname{aac}\left(6^{\prime}\right)-11 a$ & Aminoglycosides & Pseudomonadaceae \\
\hline $\operatorname{ant}\left(2^{\prime \prime}\right)-1 \mathrm{a}$ & Aminoglycosides & Enterobacteriaceae \\
\hline aph $\left(3^{\prime}\right)-1 \mathrm{a}$ & Aminoglycosides & Enterobacteriaceae \\
\hline$b^{\prime a} a_{\text {oxa }}$ & Beta-lactams & Enterobacteriaceae, Pseudomonadaceae \\
\hline bla & Beta-lactams & Haemophilus species, \\
\hline bla $_{\text {shi }}{ }^{+}$ & Beta-lactams & Enterobacteriaceae \\
\hline bla $_{\text {tem }}{ }^{+}$ & Beta-lactams & Enterobacteriaceae, Haemophilus species, \\
\hline blaz & Beta-lactams & Enterococcus species, \\
\hline dhfr & Trimethoprim & Enterobacteriaceae \\
\hline ermA & Macrolides & Staphylococcus species \\
\hline ermB & Macrolides & Enterobacteriaceae, Staphylococcus species \\
\hline $\mathrm{ermC}$ & Macrolides & Enterobacteriaceae, Staphylococcus species \\
\hline gyrA* & Quinolones & Enterobacteriaceae, Staphylococcus species, Streptococcus species, Pseudomonadaceae \\
\hline$n f x C^{\ddagger}$ & Quinolones & Pseudomonadaceae \\
\hline $\operatorname{parC} C^{\ddagger}$ & Quinolones & Enterobacteriaceae, Staphylococcus species, Streptococcus species \\
\hline mecA & Beta-lactams & Staphylococcus species \\
\hline msrA & Macrolides & Staphylococcus species \\
\hline$p b p^{\ddagger}$ & Beta-lactams & Streptococcus pneumoniae \\
\hline$r p o B^{\ddagger}$ & Rifampin & Mycobacterium species \\
\hline sul & Sulphonamides & Pseudomonadaceae \\
\hline $\operatorname{tet}(M)$ & Tetracycline & Widespread in both Gram-positive and Gram-negative bacteria \\
\hline $\operatorname{van} A$ & Vancomycin & Enterococcus species \\
\hline $\operatorname{van} B$ & Vancomycin & Enterococcus species \\
\hline $\operatorname{vanC}$ & Vancomycin & Enterococcus species \\
\hline
\end{tabular}

* Bacteria having high incidence for the specified antibiotic resistance genes. The presence of these antibiotic resistance genes in other bacteria is not excluded. ${ }^{+}$Nucleotide mutations in blashv and blatem are associated with extended spectrum beta-lactamases. ${ }^{\ddagger}$ Resistance is associated with chromosomal mutations

bacterial species for the tuf gene coding for a translation elongation factor. These sequences have been used for the universal detection of bacteria as well as for the detection of a variety of bacteria at the species, genus or family levels.

Antibiotic resistance genotypes: Resistance to antimicrobial agents in bacteria is mediated mainly by the acquisition of genes associated with a resistance phenotype $(27,28)$. In fact, it is believed that $90 \%$ to $95 \%$ of bacterial resistance to a given drug is attributable to the acquisition of a particular resistance gene. Table 2 provides a list of clinically important antibiotic resistances that can be detected by genetic methods. These resistance loci are acquired via natural mechanisms of intraand/or interspecies exchanges of genetic material (ie, conjugation, transformation and transduction). In bacteria, the exchange of resistance genes is frequently mediated by plasmids (self-replicating extrachromosomal DNA) and transposons (mobile genetic elements that can integrate into the chromosome or into plasmids). It is important to note that several different genes may confer the same resistance phenotype (eg, bla $_{\text {tem }}$, bla $_{\text {shv }}$, bla $_{\text {rob }}$ and $b l a_{\text {oxa }}$ are all associated with ampicillin resistance, and tetracycline resistance can be mediated by at least 15 different genes) (27-33). Different mutations in the resistance genes bla tem, bla shv or bla $a_{\text {oxa }}$ may be associated with distinct phenotypes $(27,28,31-33)$. The selective pressure caused by the overuse of cephalosporins in clinical treatment has led to a variety of genetic mutations that transformed the original beta-lactamases (enzymes inactivating beta-lactam antibiotics encoded by the resistance genes blatem, bla shv $_{\text {or }}$ $\left.b_{l} a_{\text {oxa }}\right)$ into new extended-spectrum beta-lactamases, which can inactivate a broad spectrum of beta-lactam antibiotics including cephalosporins. (The reader is referred to the Lahey Clinic website [www.lahey.org/studies/webt.htm] for an update on new beta-lactamase amino acid sequences). A method used to subclassify blatem genes based on hybridization with oligonucleotide probes that differentiate the nucleotide mutations involved in resistance to extended spectrum cephalosporins has been described (34). As more rapid and simple automated sequencing systems are becoming available, direct sequencing of blatem, blashv or bla oxa genes may be routinely performed to define further resistance genotypes.

The remaining $5 \%$ to $10 \%$ of resistance is associated with either chromosomal mutations or resistance genes not yet characterized (27). Clinically important resistances associated with chromosomal mutations are resistance to quinolones found in Enterobacteriaceae, Pseudomonadaceae, staphylococci and streptococci (35-37), resistance to rifampin found in mycobacteria $(38,39)$ and resistance to beta-lactams found in Streptococcus pneumoniae and Neisseria species (40-43). 
Resistance to quinolones and rifampin are associated with an array of single nucleotide mutations in bacterial genes (ie, gyrA, parC or $n f x C$ for quinolones and $r p o B$ for rifampin), which can be detected by several different nucleic acid-based diagnostic methods (35-39). On the other hand, resistance to beta-lactams in $S$ pneumoniae results from a remodelling of the penicillin-binding proteins (proteins that interact with beta-lactams and inactivate them) through acquisition of chromosomal DNA from other pneumococci or other streptococcal species (40-43). Furthermore, the random nature of the remodelling process creates a wide variety of rearrangements that complicate the detection of beta-lactam resistance in $S$ pneumoniae by genotypic methods.

Because most clinically important antibiotic resistance genes have been entirely sequenced and a wide variety of chromosomal and plasmidic mutations associated with resistance have been characterized, the potential of nucleic acidbased methods for the rapid detection of bacterial resistance to antibiotics is enormous. In the meantime, research teams throughout the world continue to uncover new genes and mutations associated with resistance, which are constantly created by the strong selective pressure on bacterial populations always in rapid evolution, and, consequently, adapting surprisingly rapidly to exposure to natural and synthetic antimicrobial agents. In fact, bacteria have more than 3.8 billion years' experience in adapting to changing environments, and they can double their populations in as little as 20 mins. During this long period, bacteria have built up a strong and diversified gene pool that allows them to survive adverse conditions, including exposure to antibiotics.

\section{CLINICAL SPECIMENS PREPARATION}

An optimal specimen preparation procedure must efficiently release nucleic acids (DNA, RNA or both) from the target bacteria, prevent degradation of the free nucleic acid by nucleases (bacterial enzymes digesting nucleic acids) and remove or neutralize inhibitors of nucleic acid amplification or hybridization, which are frequently present in clinical specimens (44-46). Furthermore, an optimal procedure for specimen preparation must take into account the specimen type tested as well as the minimal bacterial load of the target organism(s), which should be detected for this particular type of specimen based on clinical data. For example, if the concentration of the target organism is very low, such as in blood samples or in cerebrospinal fluids, concentration of the bacteria (by centrifugation) or of the nucleic acids (by ethanol precipitation or specific binding to resins followed by elution) may be required.

The type of nucleic acid to be isolated (DNA versus RNA) is also important. RNA is generally more difficult to stabilize than DNA and, consequently, procedures for RNA extraction are often more complex. However, the availability of standardized commercial kits for effective RNA extraction has simplified RNA isolation (Table 3). RNA is often used as the target nucleic acid for viral detection (eg, determination of viral load for human immunodeficiency virus or detection of RNA viruses such as enteroviruses and hepatitis $C$ virus). Although
TABLE 3

Popular commercially available kits for nucleic acid isolation from bacteria in various clinical specimens

\begin{tabular}{|c|c|c|c|}
\hline $\begin{array}{l}\text { Manufacturer } \\
\text { (location) }\end{array}$ & Product name & $\begin{array}{c}\text { Nucleic } \\
\text { acid } \\
\text { isolated }\end{array}$ & $\begin{array}{l}\text { Time } \\
(\operatorname{mins})\end{array}$ \\
\hline AMBION (Texas) & To-TALLY RNA & RNA & 120 \\
\hline \multirow[t]{2}{*}{ Bio101 (California) } & FastDNA Kit & DNA & 25 \\
\hline & FastRNA Blue Kit & RNA & 30 \\
\hline Bio-Rad (California) & InstaGene Matrix & DNA & 45 \\
\hline $\begin{array}{l}\text { DYNAL } \\
\text { (Oslo, Norway) }\end{array}$ & $\begin{array}{l}\text { Dynabeads DNA } \\
\text { DIRECT System I }\end{array}$ & DNA & 15 \\
\hline $\begin{array}{l}\text { Life Technologies } \\
\text { (Maryland) }\end{array}$ & DNAzol & DNA & 30 \\
\hline $\begin{array}{l}\text { Organon Technika } \\
\text { (North Carolina) }\end{array}$ & NucliSens Isolation kit & RNA/DNA & $150^{*}$ \\
\hline Promega (Wisconsin) & Wisard Genomic DNA & DNA & 45 \\
\hline QiAgen (California) & QiAamp tissue Kit & DNA & 150 \\
\hline \multirow[t]{2}{*}{$\begin{array}{l}\text { Roche } \\
\text { (Basel, Switzerland) }\end{array}$} & $\begin{array}{l}\text { High Pure PCR Temlate } \\
\text { Preparation Kit }\end{array}$ & DNA & 45 \\
\hline & $\begin{array}{l}\text { DNA Isolation Kit for } \\
\text { Cells and Tissue }\end{array}$ & DNA & 150 \\
\hline Stratagene (California) & DNA Extraction Kit & DNA & 120 \\
\hline
\end{tabular}

*Both RNA and DNA are extracted simultaneously. PCR Polymerase chain reaction

most nucleic acid-based diagnostic assays for bacteria target DNA, there are several advantages to the detection of RNA. Detection of rRNA allows an increased sensitivity because there are several thousand rRNA copies in each bacterial cell. Furthermore, messenger RNA detection can be used to monitor the expression of target bacterial genes.

Despite the progress in the past decade in simplifying the release and purification of bacterial nucleic acids from various clinical specimens, there is still no simple and universal method to lyse efficiently any bacteria from any specimen type. Consequently, sample preparation still represents the most labour intensive step in nucleic acid amplification. The advent of a growing number of commercial kits for nucleic acid isolation (both DNA and RNA) from bacteria in various clinical specimens has provided new tools to simplify further sample preparation (Table 3). Unfortunately, the efficiency of these kits to release amplifiable bacterial nucleic acids is variable and greatly influenced by the ease of lysis of the target organism. It has been recently shown that many of the commercial kits listed in Table 3 are not suitable to release and purify DNA efficiently from Gram-positive bacteria such as enterococci and staphylococci, which both have a thick and resistant cell wall that is difficult to break down. On the other hand, all of these kits are suitable to release amplifiable DNA efficiently from Gram-negative bacteria such as $E$ coli, which are much easier to lyse than Gram-positive bacteria. The best performing kits for any bacteria are those including a cell wall digestion step with lysozyme (High Pure PCR Template Preparation Kit from Roche [Basel, Switzerland] and QiAamp Tissue Kit from QiAgen [Valencia, California]) or those including a cell lysis step by mechanical lysis using ceramic or silica beads 
TABLE 4

Most widely used amplification technologies with commercially available diagnostic kits for bacteria

\begin{tabular}{|c|c|c|c|}
\hline $\begin{array}{l}\text { Tech- } \\
\text { nology }\end{array}$ & $\begin{array}{l}\text { Amplification } \\
\text { method }\end{array}$ & $\begin{array}{l}\text { Manufacturer } \\
\text { (location) }\end{array}$ & Bacterial target \\
\hline PCR & Target & $\begin{array}{c}\text { Roche } \\
\text { (Basel, Switzerland) }\end{array}$ & $\begin{array}{l}\text { Chlamydia } \\
\text { trachomatis }\end{array}$ \\
\hline NASBA & Target & $\begin{array}{l}\text { Organon Technika } \\
\text { (North Carolina)* }^{*}\end{array}$ & - \\
\hline SDA & Target & $\begin{array}{l}\text { Becton Dickinson } \\
\text { (Maryland) }\end{array}$ & $\begin{array}{c}\text { C trachomatis, } \\
\text { Neisseria } \\
\text { gonorrhoeae }\end{array}$ \\
\hline TMA & Target & Gen-Probe (California) & $\begin{array}{c}\text { Mycobacterium } \\
\text { tuberculosis }\end{array}$ \\
\hline bDNA & Signal & Chiron (Massachusetts)* & - \\
\hline SSSA & Signal & $\begin{array}{l}\text { DiGene Corporation } \\
\text { (Missouri) }\end{array}$ & $\begin{array}{l}\text { C trachomatis, } \\
\text { N gonorrhoeae }\end{array}$ \\
\hline LCR & Probe & Abbott (Illinois) & $\begin{array}{l}\text { C trachomatis, } \\
\text { N gonorrhoeae }\end{array}$ \\
\hline
\end{tabular}

*Companies offering only kits for viral detection. bDNA Branched DNA; LCR Ligase chain reaction; NASBA Nucleic acid sequence-based amplification; PCR Polymerase chain reaction; SDA Stand displacement amplification; SSSA SHARP signal system assay; TMA Transcription-mediated amplification

(FastDNA Kit and FastRNA Blue Kit from Bio 101, Vista, California) (Table 3). Therefore, the performance of each of these commercial kits must be carefully evaluated for each type of clinical specimen as well as for each bacterial species tested in order to ensure that the desired level of sensitivity can be achieved.

\section{AMPLIFICATION AND DETECTION TECHNOLOGIES}

The first application of recombinant DNA technology in the field of infectious diseases was reported in 1980 (9). This study demonstrated the usefulness of DNA probes to detect enterotoxigenic $E$ coli from stool cultures. In the following decade, a variety of DNA or RNA probes specific for various bacterial pathogens became commercially available $(46,47)$. Nucleic acid probes are segments of DNA or RNA labelled with a reporter molecule, such as enzymes or chemiluminescent markers, that can bind specifically to complementary sequences of nucleic acid (ie, hybridization). Although probes for virtually all common bacterial species and antibiotic resistance genes have been developed, the overall lack of sensitivity of probe-based assays have precluded their widespread use for direct detection from clinical specimens $(44,46,47)$. In fact, the sensitivity level of those assays is around $10^{4}$ to $10^{5}$ copies of the target nucleic acid. Consequently, most of these assays are suitable for culture-confirmation purposes only.

In the mid-1980s, Kary Mullis (48) invented a method for in vitro nucleic acid amplification known as the PCR. Since that time, other in vitro nucleic acid amplification methods have also been developed (Table 4). The primary objective of those methods was to improve the sensitivity of tests based on nucleic acid detection by replicating a nucleotide sequence from a target organism. The sensitivity levels reached by am- plification technologies can be as little as a single copy of the target nucleic acid. There are three types of amplification methods $(44,46,49,50)$ : target amplification methods (including PCR, strand displacement amplification, nucleic acidbased amplification and transcription-mediated amplification), which involve repeated cycles of nucleic acid synthesis by DNA and/or RNA polymerases; probe amplification methods such as the ligase chain reaction, which relies on repeated cycles of oligonucleotide probes hybridization and joining by ligation; and signal amplification systems such as branched DNA and the SHARP signal system assay, which involves the hybridization of probes coupled with reporter groups generating a greatly increased detection signal (Table 4). Available commercial diagnostic kits for bacteria (Table 4) require at least several hours to provide results. The protocols for sample preparation generally require approximately $1 \mathrm{~h}$, while the amplification and detection steps usually take at least $2 \mathrm{~h}$.

The detection method, coupled with any of the above amplification technologies, is always based on hybridization with a DNA probe specific to internal sequences of the specific amplification product for target and probe amplification methods or the target nucleic acid for signal amplification methods $(44,46)$. The most widely used probe-based detection methods in commercial diagnostic kits include those based on immunochemistry or on the detection of fluorescence or chemiluminescence. After target amplification, conventional agarose gel electrophoresis after ethidium bromide staining may be used. Although widely used in research laboratories, this method is not as specific and sensitive as probe-based detection methods and, consequently, not appropriate for use in commercial diagnostic kits $(44,46)$.

It is important to note that, of all amplification techniques, PCR is the best known and still remains by far the most widely used in both research and clinical microbiology laboratories. However, there are still very few commercially available PCR kits for the detection and identification of bacteria (Table 4). In fact, all manufacturers of diagnostic kits based on amplification technologies have focused strictly on fastidious bacteria and, consequently, are limited to the detection and identification of only Chlamydia trachomatis, Neisseria gonorrhoeae and Mycobacterium tuberculosis (Table 4). It is the authors strong belief that commercial kits for nonfastidious bacteria (eg, members of Staphylococcus species, Enterococcus species, Streptococcus species, Enterobacteriaceae and Pseudomonadaceae) frequently associated with infections in humans are also needed. Furthermore, such assays should allow the concomitant detection of clinically relevant antibiotic resistance genes such as those coding for vancomycin or methicillin resistance. The development of such assays is in progress $(5,6,21,22)$.

\section{NEW NUCLEIC ACID-BASED TECHNOLOGIES SUITABLE FOR CLINICAL MICROBIOLOGY LABORATORIES}

In the near future, easy to use commercial diagnostic kits based on amplification technologies targeting both fastidious and nonfastidious bacteria, as well as a variety of clinically 
important antibiotic resistance genes, should be developed. There should also be the development of assays for the universal detection of bacteria in normally sterile clinical specimens. This will be extremely useful for rapidly screening out the high percentage of negative specimens. The ideal format of these kits for use in routine microbiology laboratories should satisfy the following criteria.

- The sample preparation protocol should be simple (involving few steps to avoid sample contamination) and rapid (less than 30 mins).

- An internal control should be included in each amplification reaction to verify the efficiency of the reaction and to ensure that there is no significant inhibition of the reaction.

- The amplification process should be automated and rapid (less than $1 \mathrm{~h}$ ).

- The amplification should be coupled with real-time or postamplification detection of the specific amplification products by hybridization with internal probes labelled with fluorophores, thereby allowing instantaneous detection.

Idaho Technology (Idaho Falls, Idaho) has developed an air thermal cycler called the Lightcycler, which allows a 45cycle PCR amplification (typically, during each PCR cycle the reaction temperature goes from about $95^{\circ} \mathrm{C}$ to $50^{\circ} \mathrm{C}$ to $65^{\circ} \mathrm{C}$ and then back to $95^{\circ} \mathrm{C}$ ) in approximately 20 mins rather than the $1.5 \mathrm{~h}$ required with standard thermal cyclers (51). Woo and collaborators (51-53) have published extensively on the use of the LightCycler for the detection of Leptospira and Leptonema species. This system is now sold by Roche. Furthermore, this commercially available technology permits the continuous monitoring of PCR product amplification (real-time detection) by fluorescence measurements. When coupled with a simple and rapid specimen preparation method, this technology appears to be quite promising for use in clinical microbiology laboratories to provide an effective means for the rapid (less than $1 \mathrm{~h}$ ) diagnosis of bacterial and other infections.

In the near future, miniaturized equipment for nucleic acid amplification and detection will be available. Cepheid (Sunnyvale, California) is developing a miniature thermal cycling instrument to amplify and detect nucleic acids by PCR in realtime by fluorescence detection (54). This portable system, which is not yet commercially available, uses silicon-based reaction chambers with integrated heaters and inexpensive electronics to control the reaction temperature precisely. Furthermore, Cepheid is also developing disposable cartridges for sample preparation that can be loaded directly onto that instrument. These cartridges allow a great reduction of risk of

\section{REFERENCES}

1. Haley RW, Culver DH, White JW, Morgan WM, Emori TG. The nationwide nosocomial infection rate. A need for vital statistics. Am J Epidemiol 1985;121:159-67.

2. Emori TG, Gaynes RP. An overview of nosocomial infections, cross-contamination between the clinical samples because they contain all necessary reagents, reaction chambers, waste chambers and microfluidic components to extract and concentrate nucleic acids from clinical samples. These technologies will soon be compatible for use in clinical microbiology laboratories because they are simple to use, rapid (less than $1 \mathrm{~h}$ ) and relatively inexpensive.

A number of companies are actively working in the emerging field of DNA chip technology (55-57). This technology is rapidly advancing, and applications to diagnostics, gene discovery, gene expression and mapping have been demonstrated. The basic principle of this technology relies on the hybridization of a nucleic acid target labelled with a fluorescent dye to an extremely large set of oligonucleotide DNA probes located at precise positions on a miniaturized glass substrate. DNA chips are typically glass or silicon slides of $1 \mathrm{~cm}^{2}$ onto which as many as 1,000,000 labelled probes are bound. Specific hybridization with each probe, which is performed after nucleic acid amplification, is monitored by a computer-based system analyzing the fluorescence signal at each probe site. Such high-density DNA probe arrays have been already applied for the screening of mutations in several viral and bacterial genes $(39,58)$. DNA probe arrays based on 165 rRNA and rpoB sequences have recently been used for species identification within the genus Mycobacterium and simultaneous detection of nucleotide mutations associated with rifampin resistance in this bacterial genus (39). DNA chip technologies will be increasingly applicable to rapid bacterial identification and detection of antibiotic resistance in the near future.

\section{CONCLUSIONS}

Several factors, including the rapidly growing database of nucleotide sequences from a variety of bacteria, the development of increasingly simpler and faster protocols for nucleic acid extraction, and the emergence of new technologies allowing more effective nucleic acid amplification and detection, are essential ingredients for the development of commercial kits suitable for the rapid diagnosis of bacterial infections. To be efficiently integrated into clinical microbiology laboratories, these kits should be simple to use, rapid (around $1 \mathrm{~h}$ or less) and accompanied by a complete education and training program for clinicians and laboratory personnel. These much needed diagnostic tools should allow bacterial detection and identification at different levels (species, genus, family or universal) as well as the simultaneous detection of a wide variety of antibiotic resistance genotypes. These new diagnostic tools will revolutionize the diagnosis of bacterial infections by providing clinicians with key information that is essential to prescribe better and less costly treatments to patients and, consequently, reduce the use of antibiotics and, hence, the emergence of bacterial resistance. The impact on health care costs will be important.

including the role of the microbiology laboratory. Clin Microbiol Rev 1993;6:428-42.

3. Levy SB. Balancing the drug-resistance equation. Trends Microbiol 1994;2:341-2. 
4. Bauer AW, Kirby WMM, Scherris JC, Turck M. Antibiotic susceptibility testing by a standardized single disk method. Am J Clin Pathol 1966;45:493-6.

5. Bergeron MG, Ouellette $M$. Diagnosing bacterial infectious diseases in one hour: an essential upcoming revolution. Infection 1995;23:69-72.

6. Bergeron MG, Ouellette M. Preventing antibiotic resistance through rapid genotypic identification of bacteria and of their antibiotic resistance genes in the clinical microbiology laboratory. J Clin Microbiol 1998;36:2169-72.

7. McCaig LF, Hughes JM. Trends in antimicrobial drug prescribing among office-based physicians in the United States. JAMA $1995 ; 273: 214-9$.

8. Baquero F. Antibiotic resistance in Spain: what can be done? Task Force of the General Direction for Health Planning of the Spanish Ministry of Health. Clin Infect Dis 1996;23:819-23.

9. Moseley SL, Hug L, Alim ARMA, Jo M, Samapour-Motabeli M, Falkow S. Detection of enterotoxigenic Escherichia coli by DNA colony hybridization. J Infect Dis 1980;142:892-8.

10. Fox JL. Microbial genomics: Milestones mount exponentially. Nat Biotechnol 1997;15:211-2.

11. Koonin EV, Mushegian AR, Rudd KE. Sequencing and analysis of bacterial genomes. Curr Biol 1996;6:404-16.

12. Woese CR. Bacterial evolution. Microbiol Rev 1987;51:221-71.

13. Woese CR, Stackerbrant E, Macke TJ, Fox GE. A phylogenetic definition of the major eubacterial taxa. Syst Appl Microbiol 1985;6:143-51.

14. Brecher ME, Boothe G, Kerr A. The use of a chemiluminescencelinked universal bacterial ribosomal RNA gene probe and blood gas analysis for the rapid detection of bacterial contamination in white cell-reduced and nonreduced platelets. Transfusion 1993;33:450-7.

15. Greisen K, Loeffelholz M, Purohit A, Leong D. PCR primers and probes for the $16 S$ rRNA gene of most species of pathogenic bacteria, including bacteria found in cerebrospinal fluid. J Clin Microbiol 1994;32:335-51.

16. Scheinert P, Krausse R, Ullmann U, Soller R, Krupp G. Molecular differentiation of bacteria by PCR amplification of the $165-23 S$ rRNA spacer. J Microbiol Methods 1996;26:103-17.

17. Widjojoatmodjo MN, Fluit AC, Verhoef J. Molecular identification of bacteria by fluorescence-based PCR-single-strand conformation polymorphism analysis of the 165 rRNA gene. J Clin Microbiol 1995;33:2601-6.

18. Baldauf SL, Palmer JD, Doolittle WF. The root of the universal tree and the origin of eukaryotes based on elongation factor phylogeny. Proc Natl Acad Sci USA 1996;93:7749-54.

19. Goh SH, Potter S, Wood JO, Hemmingsen SM, Reynolds RP, Chow AW. HSP60 gene sequences as universal targets for microbial species identification: Studies with coagulase-negative staphylococci. J Clin Microbiol 1996;34:818-23.

20. Luneberg E, Jensen JS, Frosch M. Detection of Mycoplasma pneumoniae by polymerase chain reaction and nonradioactive hybridization in microtiter plates. J Clin Microbiol 1993;31:1088-94

21. Martineau F, Picard FJ, Roy PH, Ouellette M, Bergeron MG. Species-specific and ubiquitous DNA-based assays for rapid identification of Staphylococcus aureus. J Clin Microbiol 1998;36:618-23.

22. Martineau F, Picard FJ, Roy PH, Ouellette M, Bergeron MG. Species-specific and ubiquitous DNA-based assays for rapid identification of Staphylococcus epidermidis. J Clin Microbiol 1996;34:2888-93

23. Pasternack R, Vuorinen P, Pitkajarvi T, Koskela M, Miettinen A. Comparison of manual amplicor PCR, Cobas Amplicor PCR, and LCX assays for detection of Chlamydia trachomatis infection in women by using urine specimens. J Clin Microbiol 1997:35:402-5.

24. Mahony JB, Luinstra KE, Tyndall M, Sellors JW, Krepel J, Chernesky M. Multiplex PCR for detection of Chlamydia trachomatis and Neisseria gonorrhoeae in genitourinary specimens. J Clin Microbiol 1995;33:3049-53.

25. Rajalahti I, Vuorinen P, Nieminen MM, Miettinen A. Detection of Mycobacterium tuberculosis complex in sputum specimens by the automated Roche cobas amplicor mycobacterium tuberculosis test. J Clin Microbiol 1998;36:975-8.

26. Lindbrathen A, Gaustad P, Hovig B, Tonjum T. Direct detection of
Mycobacterium tuberculosis complex in clinical samples from patients in Norway by ligase chain reaction. J Clin Microbiol 1997;35:3248-53.

27. Tenover FC, Popovic T, Olsvik O. Genetic methods for detecting antibacterial resistance genes. In: Murray PR, Baron EJ, Pfaller MA, Tenover FC, Yolken RH, eds. Manual of Clinical Microbiology. Washington: American Society for Microbiology Press, 1995:1368-78.

28. Guillaume A, Philippon A. PCR-based approaches for the detection of bacterial resistance. In: Ehrlich GD, Greenberg SJ, eds. PCR-based Diagnostics in Infectious Disease. Boston: Blackwell Scientific Publications, 1994:665-87.

29. Roberts MC. Tetracycline resistance determinants: mechanisms of action, regulation of expression, genetic mobility, and distribution. FEMS Microbiol Rev 1996;19:1-24.

30. Marshall B, Tachibana C, Levy SB. Frequency of tetracycline resistance determinant classes among lactose-fermenting coliforms. Antimicrob Agents Chemother 1983;24:835-40.

31. Bush K, Jacoby G. Nomenclature of TEM beta-lactamases. J Antimicrob Chemother 1997;39:1-3.

32. Bush K, Jacoby GA, Medeiros AA. A functional classification scheme for beta-lactamases and its correlation with molecular structure. Antimicrob Agents Chemother 1995;39:1211-33.

33. Mee BJ, Liu Y, Munns SE. The epidemiology, genetics, and molecular features of the beta-lactamases in the genus Klebsiella with particular emphasis on extended-spectrum beta-lactamases. Recent Res Devel Antimicrob Agents Chemother 1997;2:1-13.

34. Mabilat C, Courvalin P. Development of "oligotyping" for characterization and molecular epidemiology of TEM beta-lactamases in Enterobacteriaceae. Antimicrob Agents Chemother 1990;34:2210-6.

35. Acar JF, Goldstein FW. Trends in bacterial resistance to fluoroquinolones. Clin Infect Dis 1997;24(Suppl 1):S67-73.

36. Martinez JL, Alonso A, Gomez-Gomez JM, Baquero F. Quinolone resistance by mutations in chromosomal gyrase genes. Just the tip of the iceberg? J Antimicrob Chemother 1998;42:683-8.

37. Fasching CE, Tenover FC, Slama TG, et al. gyrA mutations in ciprofloxacin-resistant, methicillin-resistant Staphylococcus aureus from Indiana, Minnesota and Tennessee. J Infect Dis 1991;164:976-9.

38. Telenti A, Imboden P, Marchesi F, Schmidheini T, Bodmer T Direct, automated detection of rifampicin-resistant Mycobacterium tuberculosis by polymerase chain reaction and single-strand conformation polymorphism analysis. Antimicrob Agents Chemother 1993;37:2054-8

39. Troesch A, Nguyen H, Miyada CG, et al. Mycobacterium species identification and rifampin resistance testing with high-density DNA probes arrays. J Clin Microbiol 1999;37:49-55.

40. Coffey TJ, Dowson CG, Daniels M, et al. Horizontal transfer of multiple penicillin-binding protein genes, and capsular biosynthetic genes, in natural populations of Streptococcus pneumoniae. Mol Microbiol 1991;5:2255-60.

41. Dowson CG, Hutchison A, Spratt BG. Extensive remodeling of the transpeptidase domain of penicillin-binding protein $2 \mathrm{~B}$ of a penicillin-resistant South African isolate of Streptococcus pneumoniae. Mol Microbiol 1989;3:95-102.

42. Dowson CG, Coffey TJ, Spratt BG. Origin and molecular epidemiology of penicillin-binding-protein-mediated resitance to beta-lactam antibiotics. Trends Microbiol 1994;2:361-6.

43. Laible G, Spratt BG, Hakenbeck R. Inter-species recombinational events during the evolution of altered PBP $2 X$ genes in penicillin-resistant clinical isolates of Streptococcus pneumoniae. Mol Microbiol 1991;5:1993-2002.

44. Tang Y, Procop GW, Persing DH. Molecular diagnostics of infectious diseases. Clin Chem 1997;43:2021-38.

45. Greenfield L, White TJ. Sample preparation methods. In: Persing DH, Smith TF, Tenover FC, White T, eds. Diagnostic Molecular Microbiology: Principles and Applications. Washington: American Society for Microbiology Press, 1993:122-37.

46. Podzorski RP, Persing DH. Molecular detection and identification of microorganisms. In: Murray PR, Pfaller MA, Tenover FC, Yolken RH, eds. Manual of Clinical Microbiology. Washington: American Society for Microbiology Press, 1995:130-57.

47. Tenover FC, Unger ER. Nucleic acid probes for detection and identification of infectious agents. In: Persing DH, Smith TF, 
Tenover FC, White T], eds. Diagnostic Molecular Microbiology: Principles and Applications. Washington: American Society for Microbiology Press, 1993:3-25.

48. Mullis KB. The unusual origin of the polymerase chain reaction. Sci Am 1990;262:56-65.

49. Lee HH, Morse SA, Olsvik O, eds. Nucleic Acid Amplification Technologies: Application to Disease Diagnosis. Natick: Eaton Publishing, 1997.

50. Persing DH. In vitro nucleic acid amplification techniques. In: Persing DH, Smith TF, Tenover FC, White TJ, eds. Diagnostic Molecular Microbiology: Principles and Applications. Washington: American Society for Microbiology Press, 1993:51-87.

51. Woo THS, Patel BKC, Smythe LD, Symonds ML, Norris MA, Dohnt MF. Identification of pathogenic Leptospira genospecies by continuous monitoring of fluorogenic hybridization probes during rapid-cycle PCR. J Clin Microbiol 1997;35:3140-6.

52. Woo TH, Patel BK, Cinco M, et al. Real-time homogeneous assay of rapid cycle polymerase chain reaction product for identification of Leptonema illini. Anal Biochem 1998;259:112-7.

53. Woo TH, Patel BK, Smythe LD, Norris MA, Symonds ML, Dohnt MF. Identification of pathogenic Leptospira by TaqMan probe in a Lightcycler. Anal Biochem 1998;256:132-4.

54. Northrup MA. A miniature analytical instrument for nucleic acids based detection on micromachined silicon reaction chambers. Anal Chem 1998;70:918-22.

55. Kricka LJ. Revolution on a square centimeter. Nat Biotechnol 1998; 16:513-4.

56. Ramsay G. DNA chips: State-of -the art. Nat Biotechnol 1998;16:40-4.

57. Marshall A, Hodgson J. DNA chips: an array of possibilities. Nat Biotechnol 1998;16:27-31.

58. Kozal MJ, Shah N, Shen N, et al. Extensive polymorphisms observed in HIV-1 clade B protease gene using high-density oligonucleotide arrays. Nat Med 1996;2:753-9. 


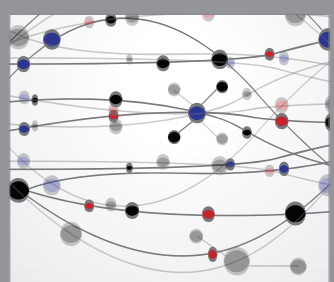

The Scientific World Journal
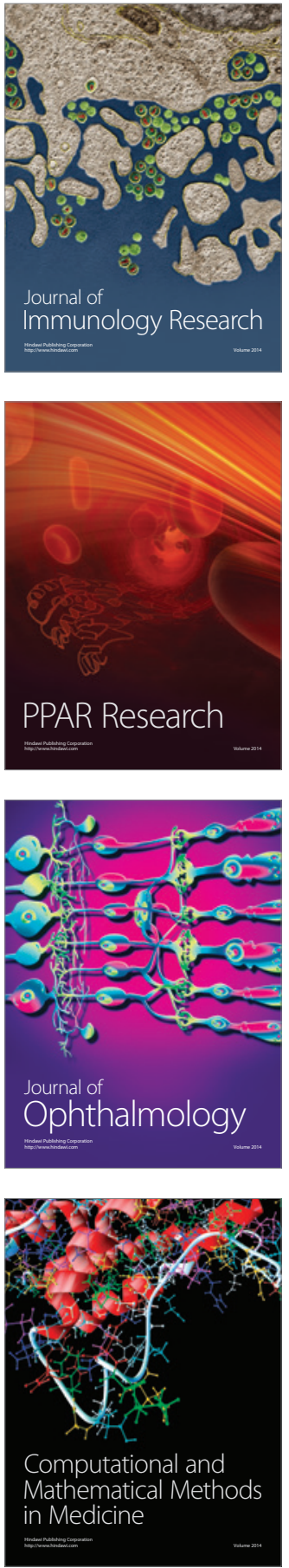

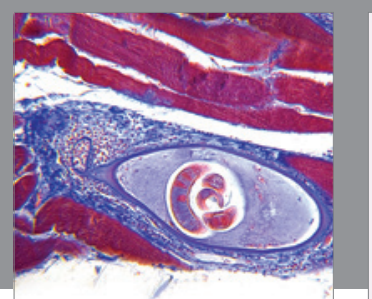

Gastroenterology Research and Practice

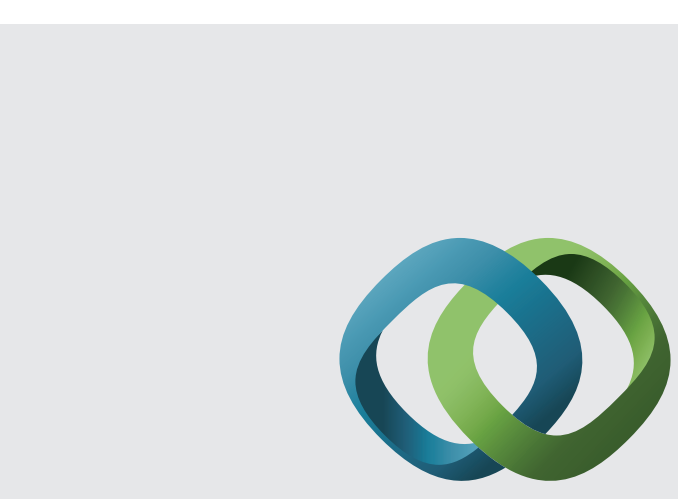

\section{Hindawi}

Submit your manuscripts at

http://www.hindawi.com
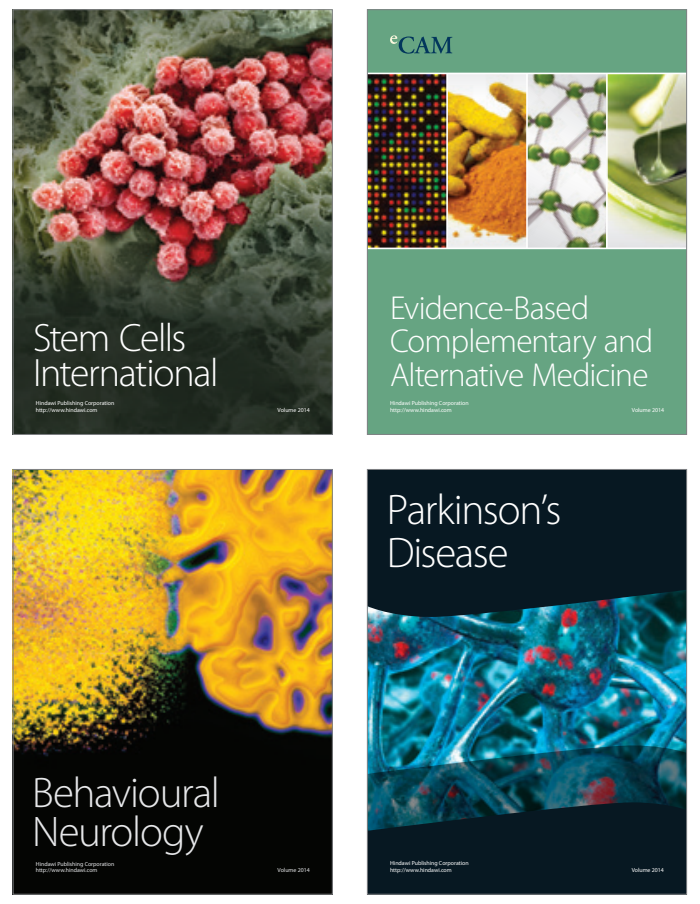
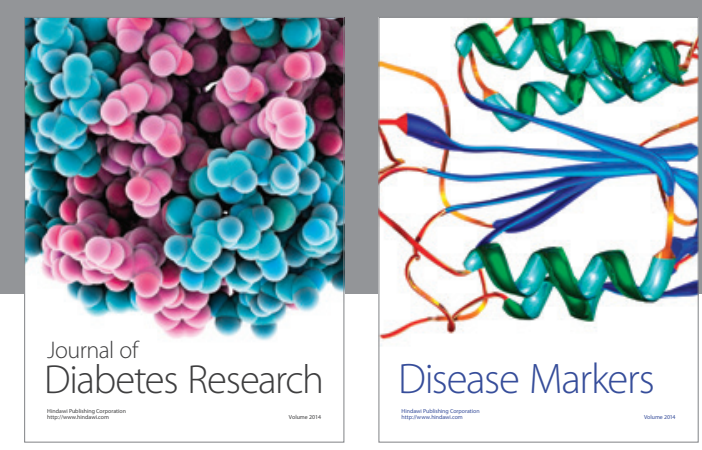

Disease Markers
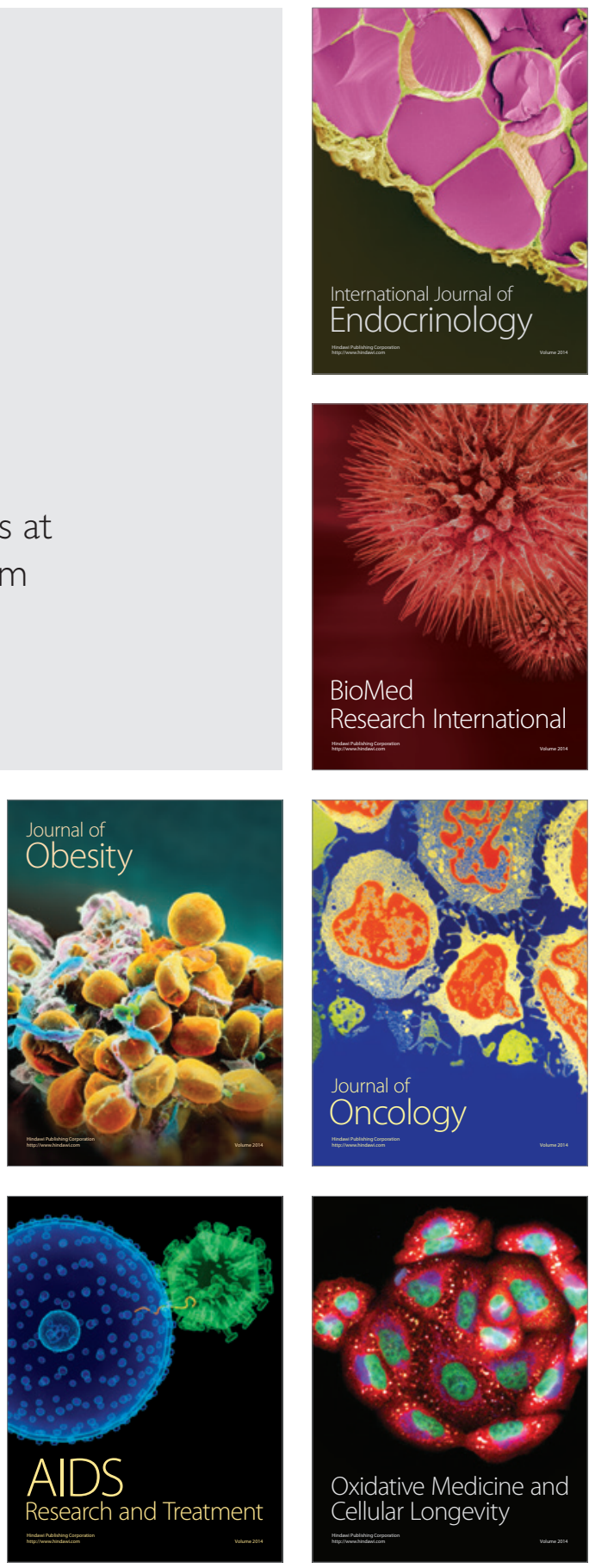